\title{
UPAYA PEMERINTAH KABUPATEN LOMBOK TIMUR DALAM MEWUJUDKAN PELESRTARIAN DAN KEBERLANJUTAN TATA RUANG DAERAH
}

\author{
Suhardi', Darmansyah ${ }^{2}$,Novia Suhastini ${ }^{3}$ \\ Jurusan Studi Pemerintahan Universitas Muhammadiyah Mataram \\ Email: noviasuhastini@ymail.com
}

\begin{abstract}
ABSTRAK
Setiap daerah otonom diberikan hak mengatur rumah tangganya sendiri termasuk menetapkan berbagai kebijakan sesuai kewenangan masing-masing. Salah satu kewenangan yang diberikan kepada daerah berupa pengelolaan tata ruang daerah dengan memperhatikan aspek lingkungan, kependudukan, kemampuan keuangan dan sumber daya manusia sebagai potensi yang dimiliki. Penataan ruang menuntut kejelasan pendekatan dalam proses perencanaannya demi menjaga keselarasan, keserasian, keseimbangan, dan keterpaduan antar daerah, antara pusat dan daerah, antar sektor dan antar pemangku kepentingan. Penataan ruang diharapkan dapat mengefisienkan pembangunan dan meminimalisir konflik kepentingan dalam pemanfaatan ruang. Untuk melihat upaya pemerintah kabupaten lombok timur dalam mewujudkan pelestarian dan keberlanjutan tata ruang daerah akan menggunakan metode penelitian kualitatif deskriptif, dengan menjabarkan hasil temuan lapangan dengan menggunakan tehnik observasi, wawancara, dokumentasi serta analisis data yang diperoleh di lokasi penelitian. Hasil penelitian menunjukkan terdapat kendalaa-kendala yang dihadapi pemerintah kabupaten Lombok Timur dalam mewujudkan pelesrtarian dan keberlanjutan tata ruang daerah yakni berkaitan dengan pertanian, kehutanan, pelestarian sumber daya air, masalah Tata Guna Tanah, ketidakserasian Pola Penggunaan Tanah, partisipasi masyarakat, masalah penegakan hukum dan pertambangan. Upaya yang dilakukan dalam mengatasi kendala tersebut adalah mengakomodir secara efektif dan efisien kepentingan antara pemerintah, swasta dan masyarakat khususnya dalam penggunaan lahan, program inventarisasi dan evaluasi sumber alam dan lingkungan hidup, program penyelamatan hutan, tanah dan air, program pembinaan dan pengelolaan lingkungan hidup, program pengendalian pencemaran lingkungan hidup, program rehabilitasi lahan kritis serta penegakan hukum.
\end{abstract}

\section{Kata Kunci: Upaya pelestarian, Tata ruang daerah.}

\section{LATAR BELAKANG}

Perencanaan tata ruang merupakan proses penyusunan rencana tata ruang wilayah yang mencakup wilayah administratif/pemerintahan (seperti provinsi, kabupaten dan kota) dan atau wilayah fungsional/kawasan (seperti Daerah Aliran Sungai (DAS), kawasan lindung, kawasan perkotaan, dan kawasan perdesaan) yang tercermin dalam Dokumen Rencana Tata Ruang Wilayah (RTRW). Pengelolaan tata ruang bukan saja sekedar membagi wilayah ke dalam beberapa kawasan dengan alasan percepatan pembangunan dan untuk mendatangkan investor tanpa melihat aspek hukum dan lingkungan yang dapat menimbulkan perubahan-perubahan kelestarian lingkungan. Pembangunan daerah seyogyanya dilakukan melalui penataan ruang secara lebih terpadu dan terarah, agar sumberdaya yang terbatas dapat dimanfaatkan secara efektif dan efisien. Salah satu upaya untuk mencapai hal tersebut adalah melalui penerapan prinisp Kelestarian dan berkelanjutan dimana setiap pembangunan dalam ruang yang tertata secara baik sehingga dibutuhkan penataan ruang sebagaimana prinsip tersebut, baik dalam proses perencanaan, pemanfaatan maupun pengendalian pemanfaatan ruang sebagai satu kesatuan sistem yang tidak terpisahkan, dan dilaksanakan secara terpadu, sinergi serta berkelanjutan (Syamsul Arifin 2003-2004:2).

Penataan ruang merupakan proses pembentukan kesepakatan antar pemeran pembangunan dalam pengembangan suatu kawasan atau Kota. Pembentukan kesepakatan ini terutama diperlukan agar setiap proses pemanfaatan sumber daya dapat dilakukan secara adil, sehingga tidak hanya mempertimbangkan aspek efisiensi namun juga aspek kesetaraan. Kegiatan penataan ruang terdiri dari 3 (tiga) kegiatan yang saling terkait, yaitu: perencanaan tata ruang, pemanfaatan ruang, dan pengendalian pemanfaatan ruang, dengan produk rencana tata ruang berupa Rencana Tata Ruang Wilayah (RTRW) yang secara hirarki terdiri dari Rencana Tata Ruang Wilayah Nasional (RTRWN), Rencana Tata Ruang Wilayah Provinsi (RTRWP), dan Rencana Tata Ruang Wilayah Kabupaten/Kota (RTRW Kab/kota). Ketiga rencana tata ruang tersebut harus dapat terangkum di dalam suatu rencana pembangunan sebagai acuan di dalam implementasi perencanaan pembangunan berkelanjutan di wilayah Indonesia. Sebagai payung hukum dalam penyelenggaraan penataan ruang, maka UndangUndang Penataan Ruang ini diharapkan dapat mewujudkan rencana tata ruang yang dapat mengoptimalisasikan dan memadukan berbagai 
kegiatan sector pembangunan, baik dalam pemanfaatan sumberdaya alam maupun sumberdaya buatan.

Dalam Pejelasan Undang-Undang Nomor 26 Tahun 2007 Tentang Penataan Ruang disebutkan Ruang wilayah Negara Kesatuan Republik Indonesia baik sebagai kesatuan wadah yang meliputi ruang darat, ruang laut dan ruang udara, termasuk ruang di dalam bumi, maupun sebagai sumber daya merupakan karunia Tuhan Yang Maha Esa kepada Bangsa Indonesia yang perlu disyukuri, dilindungi dan dikelola secara berkelanjutan untuk sebesar-besar kemakmuran rakyat sesuai dengan amanat yang terkandung dalam Pasal 33 ayat (3) Undang-Undang Dasar Negara republik Indonesia Tahun 1945, serta makna yang terkandung dalam falsafah dan Dasar Negara Pancasila. Untuk mewujudkan amanat Pasal 33 ayat (3) Undang-Undang Dasar Negara Republik Indonesia tersebut, Undang-undang tentang Penataan Ruang ini menyatakan bahwa negara menyelenggarakan penataan ruang, yang melaksanakan wewenangnya dilakukan oleh pemerintah dan pemerintah daerah dengan tetap menghormati hak yang dimiliki oleh setiap orang.

Tingginya tingkat pertumbuhan penduduk terutama yang disebabkan oleh arus urbanisasi mengakibatkan pengelolaan ruang semakin berat. Selain itu daya dukung lingkungan dan sosial yang ada juga menurun, sehingga tidak dapat mengimbangi kebutuhan akibat tekanan penduduk. Masalah perekonomian yang menjadi pemicu didalam pembangunan nasional, menjadikan berbagai kegiatan pendukung ekonomi menjadi faktor utama di dalam kegiatan pembangunan. Hal tersebut berdampak pada maraknya alih fungsi lahan yang dilakukan dalam rangka melangsungkan dan mendukung kegiatan ekonomi.

Pengendalian pemanfaatan ruang dilaksanakan secara sistematik melalui penetapan peraturan zonasi, perizinan, pemberian insentif dan disinsentif, serta sanksi. Pemanfaatan ruang suatu wilayah atau daerah seringkali tidak sesuai dengan peruntukannya yang ada dalam rencana tata ruang suatu wilayah atau daerah. Kebutuhan mendesak akan ruang, baik yang disebabkan oleh pengguna ruang ilegal maupun pemerintah, telah menyebabkan alih fungsi lahan yang tidak terkendali. Hal ini terkait erat dengan rencana tata ruang yang tidak sesuai dengan prinsip kelestarian dan berkelanjutan.

Kewenangan kepada Pemerintah Daerah melalui kebijakan otonomi dan desentralisasi memberikan kesempatan bagi daerah untuk mencari berbagai sumber pendapatan baru untuk meningkatkan pendapatan asli daerah melalui berbagai kegiatan ekonomi, termasuk alih fungsi lahan tanpa memperhitungkan keberlanjutannya dalam jangka panjang. Dampak yang ditimbulkan adalah pelanggaran-pelanggaran tata ruang semakin marak terjadi yang dapat mengganggu lingkungan dan pada akhirnya dapat mengakibatkan bencana yang dapat merugikan bagi masyarakat.

Dalam pelaksanaan tata ruang, sebagaimana yang dijelaskan dalam pasal 3 Perda kabupaten Lombok Timur No. 2 Tahun 2012, RTRW Kabupaten Lombok timur di selenggarakan berdasarkan asas : a)keterpaduan , b)keserasian, keselarasan, dan keseimbangan c)keberlanjutan, d)keberdayagunaan dan keberhasilgunaan, e)keterbukaan , f)kebersamaan dan kemitraan , g)perlindungan kepentingan umum , h)kepastian hukum dan keadilan, dan i) akuntabilitas. Kemudian dalam pasal 4 menyebutkan bahwa "Tujuan penataan ruang wilayah kabupaten adalah mewujudkan ruang wilayah Lombok Timur yang aman, nyaman, produktif dan berkelanjutan dalam pengembangan agroindustri, perikanan dan kelautan serta pariwisata dengan tetap memperhatikan daya tampung dan daya dukung lingkungan.”

Pasal 3 dan pasal 4 peraturan daerah Kabupaten Lombok Timur Nomor 2 tahun 2012 tentang rencana tata ruang wilayah (RTRW) tersebut merupakan suatu landasan dasar dalam pelaksanaan tata ruang wilayah yang menunjukkan pentingnya suatu prinsip kelestarian dan berkelanjutan dalam rencana tata ruang wilayah(RTRW) suatu wilayah guna menjaga ekosistem wilayah tersebut.

\section{KERANGKA TEORITIK}

\section{Implementasi Kebijakan Publik}

Dye mendefinisikan kebijakan publik sebagai apa yang dilakukan oleh pemerintah, bagaimana mengerjakannya, mengapa perlu dikerjakan dan perbedaan apa yang dibuat. Dye seperti yang dikutip Winarno berpandangan lebih luas dalam merumuskan pengertian kebijakan, yaitu sebagai pilihan pemerintah untuk melakukan atau tidak melakukan sesuatu. Dengan mengacu pada pandangan Dye, maka keputusan-keputusan Pemerintah adalah kebijakan, namun membiarkan sesuatu tanpa ada keputusan juga merupakan kebijakan. Kebijakan publik pada dasarnya tidak permanen, tetapi harus selalu disesuaikan, karena adanya perubahan keadaan, baik masalah politik, sosial, ekonomi maupun adanya informasi yang berubah. Perubahan kebijakan publik dilakukan setelah adanya evaluasi. Perubahan dalam kebijakan publik dengan demikian adalah dinamis mengikuti perubahan yang didorong oleh perubahan lingkungan diluar maupun dari dalam organisasi publik tersebut. Munculnya permasalahan publik adalah titik awal dari perlunya keputusan pemerintah untuk membuat 
kebijakan. Masalah itu sendiri timbul karena adanya faktor ketidakseimbangan antara kebutuhan dan tersedianya sarana.

Dalam menyusun suatu kebijakan, uruturutan perlu dilalui, dari mulai perumusan masalah, dan diakhiri dengan penghentian kebijakan. Lester dan Stewart menyusun tahapan dalam enam langkah dengan uraian masing-masing dipaparkan dalam alinea berikutnya: 1) Agenda Setting, 2) Policy Formulation, 3) Policy Implementation, 4) Policy Evaluation, 5) Policy Change, 6) Policy Termination.

Pada tahap penyusunan agenda, pembuat kebijakan akan mengumpulkan masalah-masalah publik. Dari masalah-masalah yang telah dikumpulkan, kemudian dianalisa dan diikuti dengan penyusunan pembuatan kebijakan. Siklus berikutnya ialah menerapkan kebijakan tersebut dalam masyarakat, dan diikuti dengan mengevaluasi. Dengan menganalisis hasil evaluasi, maka dibuatlah penyesuaian atau perubahan bagi penyempurnaan aturan. Langkah terakhir dari siklus pembuatan kebijakan ialah mengakhiri kebijakan karena tujuan sudah tercapai.

William Dunn (1994) membagi siklus pembuatan kebijakan dalam lima tahap, yaitu: tahap pertama ialah tahap penyusunan agenda, tahap kedua melalui formulasi kebijakan, tahap ketiga berupa adopsi kebijakan, tahap keempat merupakan tahapan implementasi kebijakan dan tahap terakhir adalah tahap penilaian atau evaluasi kebijakan. Kelima tahap yang menjadi urut-urutan (hierarki) kesemuanya perlu dikelola dan dikontrol oleh pembuat yang sekaligus pelaksana kebijakan publik.

\section{Efektifitas Kebijakan Publik}

Kata efektif berasal dari bahasa Inggris yaitu effective yang berarti berhasil atau sesuatu yang dilakukan berhasil dengan baik. Kamus ilmiah populer mendefinisikan efetivitas sebagai ketepatan penggunaan, hasil guna atau menunjang tujuan. Efektivitas di definisikan oleh para pakar dengan berbeda-beda tergantung pendekatan yang digunakan oleh masing-masing pakar.

\section{Teori Koherensi}

Teori ini sering disebut The Consistense Theory of Truth. Teori ini merupakan suatu usaha pengujian (test) atas arti kebenaran. Suatu keputusan adalah benar apabila keputusan itu konsisten dengan keputusan-keputusan yang lebih dulu kita terima, dan kita ketahui kebenarannya. Keputusan yang benar adalah suatu putusan yang saling berhubungan secara logis dengan putusan-putusan lainnya yang relevan. Teori ini dipandang sebagai teori ilmiah. Teori koherensi menitikberatkan pada kesesuaian antara pengaturan yang ada dengan fakta-fakta empiris sehingga setiap tindakan yang dilakukan dapat diukur kebenaranya dan keakuratannya.

Teori koherensi erat kaitannya dengan teori korespondensi. Teori ini menjelaskan bahwa suatu kebenaran atau sesuatu keadaan benar bila ada kesesuaian antara arti yang dimaksud suatu pernyataan atau pendapat dengan objek yang dituju atau dimaksud oleh pernyataan atau pendapat tersebut. Jadi berdasarkan teori korespondensi ini, kebenaran atau keadaan dapat dinilai dengan membandingkan antara preposisi dengan fakta atau kenyataan yang berhubungan. Apabila keduanya terdapat kesesuaian (correspondence), maka preposisi tersebut dapat dikatakan memenuhi standar kebenaran. Teori ini sering dianut oleh realisme atau empirisme. K. Roger adalah seorang penganut realisme kritis Amerika, dengan pendapatnya "keadaan benar ini terletak dalam kesesuaian antara esensi atau arti yang kita berikan dengan esensi yang terdapat dalam objeknya". Rumusan teori ini bermula dari Aristoteles dan disebut sebagai penggambaran yang definisinya berbunyi "veritasest adaequation intelctuset" yang artinya kebenaran adalah penyesuaian antara pikiran dan kenyataan yang kemudian teori ini dikembangkan oleh Bertrand Russel pada zaman modern (Aca Sugandhi 1999:122).

\section{Teori Pemanfaatan}

Dalam hal pemanfaatan penggunaan tanah untuk berbagai hal termasuk dalam penyusunan RTRW di Indonesia, erat kaitannya dengan kebijakan yang di rumuskan oleh pemerintah dalam suatu peraturan perundang-undangan khususnya yang berkaitan dengan penggunaan lahan itu sendiri.

\section{Penataan Ruang}

Pasal 1 angka 1 Undang-undang No. 26 Tahun 2007 Tentang Penataan Ruang, yang dimaksud dengan ruang adalah "Wadah yang meliputi ruang darat, ruang laut, dan ruang udara, termasuk ruang di dalam bumi sebagai satu kesatuan wilayah, tempat manusia makhluk lain hidup, melakukan kegiatan, dan memelihara kelangsungan hidupnya"

Selanjutnya, dalam Keputusan Menteri Pemukiman dan Prasarana Wilayah No. 327/KPTS/2002 tentang Penetapan Enam Pedoman Bidang Penataan Ruang, yang dimaksud dengan ruang adalah: "Wadah yang meliputi ruang daratan, ruang lautan, ruang udara sebagai satu kesatuan wilayah tempat manusia dan makhluk hidup lainnya hidup dan melakukan kegiatan serta memelihara kelangsungan hidupnya."

Adapun yang dimaksud dengan wujud struktural pemanfaatan ruang adalah susunan unsur- 
unsur pembentuk rona lingkungan alam, lingkungan sosial, lingkungan buatan yang secara hirarkhis berhubungan satu dengan yang lainnya Sedang yang dimaksud dengan pola pemanfaatan ruang meliputi pola lokasi, sebaran permukiman, tempat kerja, industri, pertanian, serta pola penggunaan tanah perkotaan dan pedesaan, dimana tata ruang tersebut adalah tata ruang yang direncanakan, sedang tata ruang yang tidak direncanakan adalah tata ruang yang terbentuk secara alami, seperti aliran sungai, gua, gunung dan lain-lain (Juniarso Ridwan \& Ahmad Sodik Sudrajat 2007:24).

Selanjunya Pasal 1 angka 5 menyebutkan yang dimaksud dengan penataan ruang adalah "suatu sistem proses perencanaan tata ruang, pemanfaatan ruang dan pengendalian pemanfaatan ruang".

Tata ruang berarti susunan ruang yang teratur. Dalam kata teratur tercakup pengertian serasi dan sederhana sehingga mudah dipahami dan dilaksanakan. Karena itu pada tata ruang, yang ditata adalah tempat berbagai kegiatan serta sarana dan prasaranya. Suatu tata ruang yang baik dapat dihasilkan dari kegiatan menata ruang yang baik disebut penataan ruang. Dalam pengertian ini, penataan ruang terdiri dari tiga kegiatan utama yaitu perencanaan tata ruang, perwujudan tata ruang dan pengendalian tata ruang (M. Daud Silalahi 2001:80).

Perencanaan tata ruang merupakan kegiatan merumuskan dan menetapkan manfaat ruang dan kaitannya atau hubungan antara berbagai manfaat ruang, berdasarkan kegiatan-kegiatan yang perlu dan dapat dilaksanakan untuk memenuhi kebutuhan manusia di masa yang akan datang. Tingkat manfaat ruang ini juga akan sangat bergantung kepada pemanfaatan sumber daya alam yang tersedia atau dapat disediakan secara optimal. Dengan demikian perencanaan tata ruang akan menghasilkan rencanarencana tata ruang untuk memberikan gambaran tentang ruang mana, untuk kegiatan apa dan kapan.

\section{METODE PENELITIAN}

Teknis penggalian data di lapangan menggunakan metode penelitian kualitatif deskriptif yaitu untuk mengetahui atau menggmbarkan kenyataan dari kejadian yang diteliti sehingga memudahkan untuk mendapatkan data yang objektif dalam rangka mengetahui Upaya Pemerintah Kabupaten Lombok Timur Dalam Mewujudkan Pelestarian dan Keberlanjutan Tata Ruang Daerah. Sumber data penelitian menggunakan data sekunder dan primer yang meliputi wawancara terhadap narasumber atau informan yang dianggap sangat berpotensi dalam memberikan data yang relevan, dan data pendukung dari literatur dan dokumen serta data yang diambil dari suatu organisasi atau perusahaan dengan permasalahan di lapangan yang terdapat pada lokasi penelitian berupa bahan bacaan, bahan pustaka dan laporan-laporan penelitian.Tehnik pengumpulan data di lapangan, menggunakan tehnik observasi, wawancara, dokumentasi serta analisis dokumen yang di peroleh di lokasi penelitian.

\section{HASIL DAN PEMBAHASAN}

\section{Kendala Pemerintah Kabupaten Lombok Timur Dalam Mewujudkan Pelesrtarian Dan Keberlanjutan Tata Ruang Daerah}

Berdasarkan hasil penelitin dan wawancara penulis dengan Bapak Faturahman salah satu kepala seksi di Tata Pemerintah Pemda Kabupaten Lombok Timur, bahwa ada beberapa kendala yang timbul dalam penerapan Perda Kabupaten Lombok Timur No. 2 Tahun 2012 berkaitan dengan Rencana Tata Ruang Wilayah Kabupaten Lombok Timur dari beberapa sektor yang telah di rencanakan :

\section{a. Pertanian}

Terdapat beberapa kendala yang ada pada lahan pertanian, yaitu: Pertama, masalah pada kawasan pertanian khususnya tanaman pangan dihadapkan pada tingginya tekanan penduduk dan ketergantungan kehidupan terhadap tanah pertanian sehingga timbul pemanfaatan lahan tanpa memperhatikan segi kemampuan tanah dan pemanfaatan ruang, memperhatikan kaidah-kaidah konservasi tanah, hal ini dapat mempercepat penurunan daya dukung tanah dan kualitas lingkungan.

Kedua, masalah pada kawasan perkebunan. Masalah yang dihadapi yaitu mengenai pemanfaatan lahan yang cocok untuk lahan perkebunan, yang tentu saja yang sesuai dengan peruntukannya dalam peraturan pemanfaatan ruang.

Ketiga, masalah yang berkaitan dengan kawasan perikanan. Potensi perikanan di Kabupaten Lombok Timur sangat besar dan merupakan salah satu sector pengembangan yang dapat meningkatkan pemasukan daerah. Perikanan tersebut banyak terdapat di Keruak, Jerowaru, Pringgabaya, dan Labuhan haji. Adapun permasalahan yang ada timbul yaitu sulitnya penentuan lokasi pembudidayaan perikanan atau budidaya mutiara, rumput laut, karena harus disesuaikan dengan kondisi dan karakteristik obyek yang dibudidayakan dan tidak mengganggu kelestarian lingkungan.

Keempat, masalah yang berkaitan dengan kawasan permukiman. Kawasan permukiman di wilayah Kabupaten Lombok Timur cendrung memusat di ibukota kabupaten tepatnya di Selong dan Masbagik yang lainnya tersebar pada pusat ibu kota kecamatan. Pada umumnya permukiman 
cenderung mengarah pada sepanjang jalan utama dengan pola linier, sehingga dalam perkembangannya disekitar jalan tersebut terdapat lahan-lahan pertanian maka dalam waktu singkat akan berubah menjadi kawasan terbangun, sehingga dikhawatirkan akan mempersempit lahan pertanian potensial.

\section{b. Kawasan Hutan}

Isu/gejala terjadinya ketidak seimbangan antara jumlah penduduk dengan daya dukung lahan/penggunaan tanah, baik lahan pertanian/permukiman maupun Kawasan hutan mengakibatkan gangguan ekologis, sehingga membawa beberapa permasalahan yang menonjol, antara lain : $\quad$ (a) Adanya ketidakseimbangan/ketidakserasian antara kegiatan masyarakat dengan kegiatan pelestarian sumber daya alam yang belum terselesaikan secara tuntas, terutama dalam pengembangan pembangunan dengan membuka hutan apalagi hutan tersebut merupakan Kawasan lindung (b) Adanya tumpang tindih keperluan lahan untuk kelestarian dan perlindungan lingkungan alam dengan kebutuhan pembangunan yang mengakibatkan Kawasan pertanian digunakan sebagai permukiman penduduk maupun perdagangan dan jasa terutama di Kawasan pusat ibu kota kecamatan pada masing-masing wilayah. (c) Kurang adanya pemahaman antara lahan yang telah ditetapkan sebagai Kawasan lindung dengan hutan Kawasan produksi, sehingga tidak sedikit masyarakat yang membuka hutan guna perluasan lahan pertanian. (d) Belum berkembangnya sistem tebang pilih, sehingga berdampak terjadinya bahaya tanah longsor yang disebabkan tidakadanya tanaman penguat sebagai penyangga tanah terhadap air.

\section{c. Pemanfaatan energi Air}

Permasalahan pada pemanfaatan energy air adalah: (a) Menurunnya fungsi hutan sebagai sumber cadangan dan penahan terjadinya erosi, banjir sebagai akibat dari penebangan hutan atau pencurian kayu yang berlebihan. (b) Berubahnya peralihan fungsi kawasan lindung untuk kepentingan pembangunan sehingga menyebabkan hilangnya sumber air. (c) Kurang adanya pengembangan/pembuatan Dam ataupun semacam waduk untuk penampungan air, sehingga pada waktu musim kemarau air tersebut dapat digunakan sebagai pengairan irigasi cadangan. (d) Kurang terkoordinasinya pemanfaatan sumber mata air, sehingga air yang keluar tidak akan terbuang percuma dan dapat dimanfaatkan untuk irigasi pertanian. seperti yang yang penulis jelaskan bahwa Ketersediaan air Kabupaten Lombok Timur ditunjang dengan adanya 10 sungai yang tersebar di wilayah
Kabupaten Lombok Timur, selain sungai banyak sekali terdapat sumber mata air yang tersebar diseluruh wilayah dengan jumlah 259 titik sumber air baik yang masih aktif ataupun sudah tidak aktif mengeluarkan air. Namun tetap tidak bisa menunjang kebutuhan air di Kabupaten Lombok Timur secara optimal.

\section{d. Ketidakserasian Pola Penggunaan Tanah (Land Use Conflicts).}

Dalam pengembangan tata ruang wilaya aspek yang perlu diperhatikan adalah menyerasikan pola penggunaan tanah dengan peruntukan yang sesuai dengan potensi fisik dan sosial masing-masing daerah. Semakin tinggi taraf hidup masyarakat dan semakin tinggi tingkat teknologinya, menyebabkan peningkatan permintaan kebutuhan pokok kehidupan, maka dengan meningkatnya jumlah penduduk dan meningkatnya kegiatan pembangunan menyebabkan semakin meningkatnya permintaan bahan kebutuhan yang dihasilkan oleh sumber daya alam. Beberapa kegiatan pemanfaatan sumber daya alam yang menjadi sumber penghasilan masyarakat adalah pertanian, perkebunan, kehutanan, peternakan dan transportasi serta permukiman penduduk sehingga kegiatan manusia tambah tinggi sementara sumber daya alam yang tersedia sangat terbatas, terutama adalah lahan. Penggunaan lahan yang tidak sesuai juga disebabkan antara lain oleh kondisi sosial ekonomi masyarakat setempat, yang kurang memperhatikan tata cara kehidupan. Dalam kebutuhan yang mendesak yang perlu dicukupi dalam jangka pendek menyebabkan luas lahan pertanian cenderung menurun untuk penggunaan lahan non pertanian sertai perumahan, pelebaran jalan dan lainlain. Kurangnya pengetahuan masyarakat akan teknik-teknik konservasi tanah menyebabkan terjadinya pemanfaatan yang tidak serasi disertai dengan teknik konservasi tanah yang sesuai, sehingga tak jarang terjadi erosi pada tanah sedimentasi pada alur sungai yang melampui batas yang ditetapkan, banjir dimusim hujan dan kekeringan dimusim kemarau serta menurunnya hasil produktifitas merupakan indikator bahwa kerusakan sumber daya alam dan lingkungan telah terjadi yang dapat digolongkan sebagai gejala ketidakserasian penggunaan lahan.

\section{e. Dari sisi partisipasi masyarakat.}

Faktor-faktor yang menyebabkan anggota masyarakat tidak mematuhi dan melaksanakan suatu kebijakan publik, yaitu : (1) Adanya konsep ketidakpatuhan selektif terhadap hukum,dimana terdapat beberapa peraturan perundang-undangan atau kebijakan public yang bersifat kurang mengikat individu- individu: (2) Karena anggota masyarakat dalam suatu kelompok atau perkumpulan dimana mereka mempunyai gagasan atau pemikiran yang 
tidak sesuai atau bertentangan dengan peraturan hukum dan keinginan pemerintah: (3) Adanya keinginan untuk mencari keuntungan dengan cepat diantaranya anggota masyarakat yang mencenderungkan orang bertindak dengan menipu atau dengan jalan melawan hukum: (4) Adanya ketidakpastian hukum atau ketidakjelasan "ukuran" kebijakan yang mungkin saling bertentangan satu sama lain, yang dapat menjadi sumber ketidak patuhan orang pada hokum atau kebijakan publik: (5) Apabila suatu kebijakan ditentang secara tajam (bertentangan) dengan system nilai yang dianut masyarakat secara luas atau kelompok-kelompok tertentu dalam masyarakat.

\section{f. Lemahnya penegakan hukum}

Lemahnya penegakan hukum terhadap pelanggaran membuang sampah sembarangan dan yang bersifat merusak lingkungan seperti illegal logging mengakibatkan semakin banyak warga yang tidak peduli dengan kebiasaan membuang sampah pada tempatnya dan semakin menggilanya para cukong kayu membabat habis hutan. Tidak ada penindakan sama sekali terhadap "para pembuang sampah sembarangan" dan pelanggar hukum lingkungan lainnya yang notabene seharusnya sudah memahami arti penting kelestarian lingkungan.

\section{g. Pertambangan}

Salah satu permasalahan Tata Ruang yang saat ini menjadi fokus utama masyarakat Lombok timur adalah pelaksanaan penambangan pasir dalam rangka program reklamasi di Teluk Benoa Bali. Pelaksanaan reklamasi teluk benoa, Nusa Dua Bali merupakan salah satu program Rencana Tata Ruang khususnya Kawasan Perkotaan Denpasar, Badung, Gianyar dan Tabanan berdasarkan ketentuan dalam Peraturan Presiden No 51 Tahun 2014 tentang perubahan atas Perpres 45 Tahun 2011 tentang Rencana Tata Ruang Kawasan Perkotaan Denpasar, Badung, Gianyar dan Tabanan. Penerbitan Perpres No. 51 Tahun 2014 tersebut mengubah peruntukan perairan Teluk Benoa dari kawasan konservasi menjadi zona budi daya yang dapat direklamasi maksimal 700 hektar. Dalam perencanaanya, PT Tirta Wahana Bali Internasional sebagai pihak pengembang dikabarkan akan mereklamasi 700 hektar kawasan Teluk Benoa dengan pasir dari wilayah setempat dan perairan Lombok Timur, Nusa Tenggara Barat. Terhadap rencana pengerukan pasir di Lombok Timur tersebut, Pemerintah Provinsi Nusa Tenggara Barat kemudian mengeluarkan izin guna memuluskan kebijakan reklamasi tersebut sehingga menyebabkan pro-kontra tidak hanya bagi masyarakat Lombok Timur saja, tapi bagi seluruh masyarakat yang ada di Bali dan Lombok. Disatu sisi, proyek reklamasi memang tidak dapat dipungkiri membawa sejumlah dampak positif bagi ekonomi yang akan diperoleh oleh pemerintah NTB, khususnya retribusi daerah yang kalau dinominalkan cukup menggiurkan. Namun dari sisi penanganan, kerusakan lingkungan akibat pengerukan pasir tersebut pemerintah NTB bakal menanggungnya sepanjang masa tanpa ada kewajiban apapun dari perusahaan yang melakukan pengerukan pasir pantai. Terlebih faktanya, setiap kegiatan pertambangan selama ini, akibat yang ditimbulkan terhadap kerusakan alam tidak mudah dan jarang dapat diperbaharui kembali seperti keadaan lingkungan semula.

\section{Upaya-Upaya Yang Dilakukan Pemerintah Kabupaten Lombok Timur Dalam Mengatasi Kendala Dalam Mewujudkan Pelesrtarian Dan Keberlanjutan Tata Ruang Daerah}

Dari hasil wawancara dengan Pemda Kabupaten Lombok Timur, upaya yang sedang dilakukan adalah pada peningkatan kemampuan lahan (land capability) yang saat ini kurang produktif menjadi lebih produktif. Caranya adalah dengan menata kembali kawasan tersebut agar didapatkan nilai tambah yang lebih memadai dan sesuai dengan potensi serta nilai ekonomi yang dimilikinya. Dengan kata lain, upaya peningkatan kemampuan lahan tersebut dimaksudkan agar lahan dapat dimanfaatkan sesuai dengan potensi yang dimiliki.

Dari hasil wawancara penulis dengan bapak Faturahman salah satu kepala seksi di Tata Pemerintah Pemda Kabupaten Lombok Timur, ada beberapa upaya yang saat ini sedang dilaksanakan pemerintah Kabupaten Lombok Timur dalam menanggulangi kendala-kendala penerapan perda Kabupaten Lombok Timur No 2 Tahun 2012 sebagaimana mana yang telah penulis jelaskan sebelumnya yakni :

a. Mengakomodir secara efektif dan efisien kepentingan antara pemerintah, swasta dan masyarakat khususnya dalam penggunaan lahan. Hal ini perlu diperhatikan khususnya dalam pemberian izin penggunaan lahan pertanian.

b. Program Penyelamatan Hutan, Tanah dan Air. Program ini bertujuan untuk melestarikan fungsi dan kemampuan sumber alam hayati dan non hayati serta lingkungan hidup melalui penyelamatan hutan, tanah dan air yang merupakan sumber alam dan sekaligus pula lingkungan hidup. Oleh karena itu pengelolaan secara terarah sumber-sumber alam ini akan sangat menentukan keseimbangan sistem pengendalian tata air, laju erosi, dan besaran akumulasi sedimentasinya. Peningkatan kapasitas pengelolaan kawasan suaka alam dan kawasan pelestarian alam baik daratan maupun lautan termasuk flora dan fauna dan keunikan alamnya, 
dilakukan untuk melindungi dan mengawetkan keanekaragaman hayati plasma nutfah, dan ekosistemnya.

c. Program Inventarisasi dan Evaluasi Sumber Alam dan Lingkungan Hidup Kabupaten Lombok Timur khususnya yang berkaitan dengan tata guna tanah. Program ini pada dasarnya bertujuan untuk meningkatkan pengenalan terhadap jumlah dan mutu sumber daya alam serta mengembangkan neraca dan tata guna sumber alam dan lingkungan hidup untuk mengetahui daya dukung dan menjamin ketersediaan sumber alam yang berkelanjutan. Hal ini perlu dilakukan untuk mengetahui sejauhmana kelangsungan tata ruang dan lingkungan hidup di Kabupaten Lombok Timur. Dengan demikian kita dapat mengetahui dan mengevaluasi kondisi tata ruang dan lingkungan hidup di Kabupaten Lombok Timur. Apabila ada hal yang perlu dilakukan misalnya tindakan berupa rehabilitasi, maka hal tersebut tidak boleh lagi ditunda-tunda dalam rangka penyelamatan tata ruang dan lingkungan hidup. Namun berdasarkan hasil penelitian penulis yang diperoleh khususnya tindakan berupa penyelamatan terhadap kondisi misalnya peralihan fungsi hutan lindung dan peralihan fungsi lahan pertanian untuk kebutuhan lahan industri dan perumahan sampai saat ini belum direalisasikan.

d. Pengendalian Ketidakserasian Pola Penggunaan Tanah

Pengendalaian pola penggunaan tanah ini sangat erat kaitannya dengan persoalan pemberian izin penggunaan tanah. Oleh sebab itu, pemerintah Kabupaten Lombok Timur sangat memperhatikan pola-pola penggunahan lahan produktif yang boleh atau tidak boleh diberizin untuk pembangunan di daerah tersebut.

e. Partisipasi mayarakat.

Dalam kegiatan penataan ruang masyarakat berhak antara lain Pertama, berperan serta dalam proses perencanaan tata ruang, pemanfaatan ruang, dan pengendalian pemanfaatan ruang Kabupaten. Kedua, mengetahui secara terbuka rencana tata ruang wilayah, rencana tata ruang kawasan, rencana rinci tata ruang kawasan, termasuk tata letak dan tata bangunan Kabupaten Lombok Timur. Ketiga, menikmati manfaat ruang dan atau pertambahan nilai ruang sebagai akibat dari penataan ruang Kabupaten Lombok Timur. Keempat, memperoleh penggantian yang layak atas kondisi yang dialami sebagai akibat pelaksanaan kegiatan pembangunan yang sesuai dengan rencana tata ruang Kabupaten Lombok Timur. Pelaksanaan hak masyarakat dalam menikmati manfaat ruang dilaksanakan sesuai dengan ketentuan peraturan perundangundangan atau kaidah yang berlaku. Dalam hubungannya dengan pelaksanaan hak masyarakat tersebut Pemerintah Kabupaten Lombok Timur berkewajiban melakukan pembinaan, menyebarluaskan informasi dan memberikan penjelasan kepada masyarakat tentang ketentuan peraturan perundangundangan atau kaidah yang berlaku. Selain hak atau peran tersebut, masyarakat juga harus mempunyai kewajiban dalam pelaksanaan fungsi tata ruang Kabupaten Lombok Timur yakni berperan serta dalam memelihara kualitas ruang, dan berlaku tertib dalam keikutsertaannya dalam proses perencanaan tata ruang pemanfaatan ruang, dan menaati rencana tata ruang yang telah ditetapkan. Pelaksanaan kewajiban masyarakat dalam penataan ruang dilaksanakan dengan mematuhi dan menerapkan kriteria, kaidah, baku mutu, dan aturan-aturan penataan ruang yang ditetapkan dengan peraturan perundangundangan.

Peran serta masyarakat dalam proses perencanaan tata ruang wilayah Kabupaten Lombok Timur dapat berbentuk sebagai berikut: Pertama, pemberian masukan untuk menentukan arah pengembangan wilayah yang akan dicapai. Kedua, pengidentifikasian berbagai potensi dan masalah pembangunan termasuk bantuan untuk memperjelas hak atas ruang wilayah, termasuk perencanaan tata ruang kawasan. Ketiga, pemberian masukan dalam merumuskan perencanaan tata ruang wilayah Kabupaten Lombok Timur. Keempat, pemberian informasi, saran, pertimbangan atau pendapat dalam penyusunan strategi pelaksanaan pemanfaatan ruang wilayah Kabupaten Lombok Timur. Kelima, pengajuan keberatan terhadap rancangan Rencana Tata Ruang Wilayah Kabupaten. Keenam, kerja sama dengan penelitian dan pengembangan; dan atau Ketujuh, bantuan tenaga ahli.

f. Penegakan hukum

Menurut Soerjono Soekanto ada beberapa faktor yang mempengaruhi penegakan hukum, yaitu : 1)Hukumnya sendiri, 2)Penegak hukum, 3)Sarana dan fasilitas, 4)Masyarakat, 5)Kebudayaan. Kelima faktor tersebut sangatlah menunjang bagaimana efektifitas kebijakan publik itu dapat berjalan sebagaimana mestinya.

7. Penanggulangan permasalahan penambangan pasir

Sampai saat ini pelaksanaan penambangan pasir di Lombok Timur dalam rangka reklamasi Teluk Benoa masih berlangsung sehingga sebagian masyarakat Lombok Timur dan berbagai LSM 
yang tidak setuju dengan kegiatan tersebut terus melakukan perlawanan terhadap tindakan pemerintah Provinsi Nusa Tenggara Barat yang telah memberikan izin. Berbagai mediasi telah dilakukan antara pemerintah daerah, pihak investor dan masyarakat guna mencari solusi terbaik. Namun masing-masing pihak tetap mempertahankan kehendaknya sehingga sampai hari ini belum ada solusi kongkrit dalam proses penyelesaian pengerukan pasir tersebut.

Selain beberapa program khusus yang telah dirancang dan sedang dilaksanakan oleh pemerintah Kabupaten Lombok Timur dalam menanggulangi permasalahan sebagaiaman dijelaskan pada bab sebelumnya, ada beberapa program secara umum yang juga sedang dilaksanakan pemerintah Kabupaten Lombok Timur guna menunjang programporgram dalam menanggulangi masalah tata ruang tersebut agar penerapan perda Kabupaten Lombok Timur No 2 Tahun 2012 dapat berjalan secara efektif sesuai dengan prinsip kelestarian dan berkelanjutan. Program-program tersebut diantaranya :
1) Program Pembinaan dan Pengelolaan Lingkungan Hidup
2) Program Pengendalian Pencemaran Lingkungan Hidup.
3) Program Rehabilitasi Lahan Kritis

\section{SIMPULAN DAN SARAN 1. Simpulan}

kendala-kendala yang dihadapi Pemerintah Kabupaten Lombok Timur dalam mewujudkan pelesrtarian dan keberlanjutan tata ruang daerah adalah berkaitan dengan pertanian, kehutanan, pelestarian sumber daya air, masalah Tata Guna Tanah, ketidakserasian Pola Penggunaan Tanah, partisipasi masyarakat, masalah penegakan hukum dan pertambangan. Kendala-kendala tersebut sangat bedampak pada ketidakefektifan penerapan perda Kabupaten No 2 Tahun 2012 tersebut sehingga perlu ada solusi kongkrit untung menanggulanginya. Beberapa upaya yang dilakukan dalam mengatasi kendala tersebut adalah sebagai berikut : mengakomodir secara efektif dan efisien kepentingan antara pemerintah, swasta dan masyarakat khususnya dalam penggunaan lahan, program inventarisasi dan evaluasi sumber alam dan lingkungan hidup, program penyelamatan hutan, tanah dan air, program pembinaan dan pengelolaan lingkungan hidup, program pengendalian pencemaran lingkungan hidup, program rehabilitasi lahan kritis serta penegakan hukum.

\section{SARAN}

1. Perlu ada kerjasama terpadu antar berbagai pihak (pemerintah, masyarakat, pihak swasta) dalam pemanfaatan fungsi tata ruang wilayah Kabupaten Lombok Timur berbagai sector umum maupun sector unggulan demi kelestarian dan berkelanjutan dimasa yang akan datang.

2. Perlu ada kesadaran dan partisipasi masyarakat dalam menjaga dan mengawasi pemanfaatan tata ruang demi kelestarian lingkungan hidup.

3. Pemerintah harus lebih selektif dalam memberikan izin penggunaan alih fungsi lahan maupun izin pertambangan baik bagi perseorangan maupun swasta serta memberikan sangsi yang tegas bagi penyalahgunaan izin lahan sebagaiamana yang diatur dalam perda Kabupaten Lombok Timur No 2 Tahun 2012.

\section{DAFTAR PUSTAKA}

\section{Buku dan Artikel}

Aca Sugandhi, 1999. Tata Ruang dalam Lingkungan Hidup. Jakarta.

Bambang Sunggono. 1994. Hukum dan Kebijakan Publik. Sinar Grafika. Jakarta.

Budi Winarno. 2002. Teori dan Proses Kebijakan Publik. Yogyakarta: Media Pressindo

Faisal Akbar, 2003. Dimensi Hukum Dalam Pemerintahan Daerah, Cetakan Pertama, Medan: Pustaka Bangsa Press.

Juniarso Ridwan \& Ahmad Sodik Sudrajat, 2007. Hukum Tata Ruang dalam konsep kebijakan otonomi daerah Cetakan I, Bandung: Nuansa.

M. Daud Silalahi, 2001. Hukum Lingkungan Dalam Sistem Penegakan Hukum Lingkungan Indonesia. Bandung: Penerbit PT. Alumni.

Philipus M. Hadjon dkk, 1994. Pengantar Hukum Administrasi Indonesia (Introduction to theIndonesian Administrative Law) (Yogyakarta, dicetak oleh : Gajah Mada University Press).

Riant Nugroho Dwijowijoto, 2004. Kebijakan Publik, Formulasi, Implementasi Dan Evaluasi. Jakarta. PT. Giwantara.

Siti Sundari Rangkuti, 2005. Hukum Lingkungan dan Kebijaksanaan Lingkungan Nasional Terhadap Rencana Tata Ruang, Surabaya: Airlangga University Press, cetakan ketiga.

Soerjono Soekamto, 1985. Sri Mamuji, "Penelitian Hukum Normatif Suatu Tujuan Singkat," Penerbit CV. Rajawali, Jakarta.

Solichin Abdul Wahab, 1997. Evaluasi Kebijakan Publik. Penerbit FIA. Unibraw dan IKIP Malang.

Syamsul Arifin, 2003-2004. Kerangka Acuan Kerja, “ Seminar Mewujudkan Kawasan Perkotaan Yang Berwawasan Lingkungan dalam Rangka Otonomi Daerah," Kerjasama Pusat Studi Lingkungan Hidup Universitas Muhammadiyah dengan Bapedalda dan Komite Aksi Pembangunan Yang Berkelanjutan Propinsi Sumatera Utara

William Dunn. 1994. Pengantar Analisis Kebijakan Publik. ( Drs. Somodra Wibawa, MA, dkk, Penterjemah). Jogyakarta: Gajah Mada University Press.

Peraturan Perundang-undangan

Indonesia, Undang-undang Dasar Negara Republik Indonesia Tahun 1945

Indonesia, Undang-undang Nomor 5 Tahun 1960 tentang Peraturan Dasar Pokok-Pokok Agraria (Lembaran Negara Tahun 1960 Nomor 104, Tambahan Lembar Negara Republik Indonesia Nomor 2034) 
Indonesia, Undang-Undang Nomor. 26 Tahun 2007 tentang Penataan Ruang (Lembar Negara Nomor 68 tahun 2007, tambahan lembar Negara Nomor 4725)

Indonesia, Peraturan Pemerintah Nomor 26 Tahun 2008 tentang Rencana Tata Ruang Wilayah Nasional

Indonesia, Peraturan Daerah Kabupaten Lombok Timur No.

2 Tahun 2012 berkaitan dengan Rencana Tata Ruang Wilayah Kabupaten Lombok Timur 